Kamila Piernik-Wierzbowska

Uniwersytet Mikołaja Kopernika, Toruń

\title{
Systematyka i zagadnienie własności zwierząt oraz ich statusu prawnego w kontekście problematyki odpowiedzialności za szkody przez nie wyrządzane
}

DOI: http://dx.doi.org/10.12775/SIT.2015.010

Polski ustawodawca wprowadził odmienne uregulowania w przedmiocie odpowiedzialności za szkody wyrządzane przez zwierzęta, uzależniając je od statusu zwierzęcia, $z$ którego zachowaniem należy wiązać wystąpienie uszczerbku. Niniejsze opracowanie dokonuje podziału zwierząt dostosowanego do przyjętych zasad odpowiedzialności.

Jednocześnie przedstawione zostanie zagadnienie statusu prawnego zwierząt ze szczególnym uwzględnieniem rozbieżnych stanowisk i poglądów dotyczących statusu właścicielskiego, odpowiedzialności za szkody wyrządzane przez zwierzęta dzikie oraz ewolucji poglądów w tym zakresie wraz z próbą zajęcia stanowiska w dyskusji. Przedmiotem niniejszego opracowania są szkody wyrządzane przez zwierzęta „Z własnego popędu”, w odróżnieniu od szkód wyrządzanych przez zwierzęta stanowiące narzędzie w ręku człowieka. 


\section{Podział zwierząt w zależności od reżimu odpowiedzialności}

Aktualnie obowiązujące akty prawne nie zawierają legalnej definicji zwierzęcia. Na gruncie nauk biologicznych ${ }^{1}$ prezentowany jest pogląd, że zwierzęta (animalia) zbudowane są z komórek zawierających jądro $z$ materiałem genetycznym DNA, są organizmami cudzożywnymi o ograniczonym wzroście i zwykle posiadają zdolność ruchu. Ustawa o ochronie zwierząt ${ }^{2}$, a zatem akt podstawowy w zakresie odnoszącym się do zwierząt, uznaje zwierzę za istotę żyjącą i zdolną do odczuwania cierpienia, a zatem nie będącą rzeczą, której człowiek winien jest poszanowanie, ochronę i opiekę. Pomimo zapisu zawartego w art. 2, uważa się, że ustawa reguluje postępowanie nie tylko ze zwierzętami kręgowymi, lecz ze wszystkimi zwierzętami ${ }^{3}$. Podkreślenia w tym miejscu wymaga, że ustanowienie odrębnych zasad odpowiedzialności za szkody wyrządzane przez pewne grupy zwierząt nie zwalnia od ponoszenia odpowiedzialności na zasadach ogólnych, a więc odpowiedzialności z tytułu kontraktu lub deliktu ${ }^{4}$.

\subsection{Zwierzęta objęte zakresem regulacji art. 431 ustawy Kodeks cywilny}

Przepis art. 431 Kodeksu cywilnego ${ }^{5}$ stanowi, że kto zwierzę chowa albo się nim posługuje, obowiązany jest do naprawienia wyrządzonej przez nie szkody niezależnie od tego, czy zwierzę było pod jego

${ }^{1}$ J. Strzałko, Słownik terminów biologicznych, Poznań 2006, s. 7.

${ }^{2}$ Ustawa $z$ dnia 21 sierpnia 1997 r. o ochronie zwierząt (Dz.U. z 1997 r. Nr 111, poz. 724 ze zm.).

${ }^{3}$ W. Radecki, Ustawa o ochronie zwierzat. Komentarz, Warszawa 2012, s. 55. Do poglądu tego przychyla się również M. Goettel, Sytuacja zwierzęcia w prawie cywilnym, Warszawa 2013, s. 237.

${ }^{4}$ Wyrok SN z dnia 17 czerwca 1966 r., I CR 360/66, Lex nr 463; Wyrok SA w Warszawie z dnia 5 marca 1999 r., I ACa 1386/98, Lex nr 40433; Uchwała SN z dnia 7 grudnia 2007 r., III CZP 120/07, Lex nr 322097.

${ }^{5}$ Ustawa z dnia 23 kwietnia 1964 r. Kodeks cywilny, Dz.U. z 2014 r., poz. 121. 
nadzorem, czy też zabłąkało się lub uciekło. W ten sposób wyróżniona została grupa zwierząt pozostających w określonej zależności od człowieka i pod jego władztwem. W świetle tej regulacji nie ma znaczenia, do jakiego gatunku zwierzę przynależy, a zatem czy będzie to zwierzę domowe, czy zwierzę dzikie, które znalazło się pod pieczą człowieka, np. w ogrodzie zoologicznym ${ }^{6}$.

Pojęcie chowu zwierząt nie zostało dookreślone przez ustawodawcę, jednakże w doktrynie prawniczej ${ }^{7}$ definiuje się je jako zespół czynności i zabiegów polegających na dostarczaniu pożywienia, zapewnieniu odpowiedniego pomieszczenia i na leczeniu w razie choroby, a zatem czynności mających zapewnić zwierzętom jak najlepsze warunki bytowania ${ }^{8}$. Większość przedstawicieli doktryny dodatkowo wymaga, aby ten, kto zwierzę chowa, czyli osoba fizyczna, osoba prawna lub jednostka organizacyjna nie posiadająca osobowości prawnej, działał dla osiągnięcia własnej korzyści, jednakże nie musi mieć ona wymiaru materialnego, lecz może być rozumiana szeroko, w tym jako satysfakcja $z$ udzielenia schronienia zabłąkanemu zwierzęciu. Można napotkać także na pogląd, zgodnie $z$ którym zwierzę chowa ten, kto sprawuje nad nim pieczę przez dłuższy $\operatorname{czas}^{9}$, przy czym trudno tu wskazywać na jakieś konkretne granice czasowe $^{10}$. Chów zwierząt odróżnia się nadto od hodowli zwierząt, która jest pojęciem szerszym i oznacza dodatkowo wykonywanie zabiegów związanych $z$ rozrodem zwierząt.

Prezentowano jednak sprzeczne poglądy dotyczące możliwości uznania niektórych zwierząt żyjących w stanie wolnym za zwierzęta

${ }^{6}$ Wyrok SN z dnia 21 listopada 1961 r., IV CR 138/61, „Orzecznictwo Sądu Najwyższego. Izba Cywilna” 1963, nr 7-8.

7 M. Goettel, Sytuacja zwierzęcia, s. 332-333.

${ }^{8}$ Definicja chowu zwierząt zawarta w art. 1 ust. 2 ustawy z dnia 18 kwietnia 1985 r. o rybactwie śródlądowym (Dz.U. z 2009 r. Nr 189, poz. 1471) nie wydaje się w tym wypadku adekwatna. Zgodnie $z$ nią, za chów zwierząt należałoby uznać „działania zmierzające do utrzymywania i zwiększania ich produkcji”, co nie znajduje zastosowania wobec zwierząt domowych takich jak psy lub koty.

${ }^{9}$ A. Szpunar, Odpowiedzialność za szkody wyrządzone przez zwierzęta i rzeczy, Warszawa 1985, s. 26.

10 M. Goettel, Sytuacja zwierzęcia, s. 333. 
chowane. Przedstawiciele części doktryny ${ }^{11}$ podnosili, że państwo i jego instytucje prowadzą wobec żyjących na wolności zwierząt zagrożonych wyginięciem działania polegające na roztaczaniu nad nimi opieki, na okresowym dokarmianiu, zapobieganiu chorobom oraz na ochronie przed zagrożeniem ze strony ludzi, co przypomina sytuację zwierząt chowanych w rozumieniu art. 431 Kodeksu cywilnego. Tym samym „odpowiedzialność z art. 431 Kodeksu cywilnego dotyczyłaby również zwierząt poddanych ustawie o ochronie przyrody, skoro ochrona ta polega między innymi na utrzymywaniu i zabezpieczeniu zasobów przyrody" ${ }^{12}$. Zaprezentowany został również pogląd ${ }^{13}$, zgodnie $z$ którym wolno żyjąca zwierzyna łowna będzie zwierzyną chowaną przez zarządcę lub dzierżawcę obwodu łowieckiego, ponieważ popadła ona w całkowitą zależność od człowieka. Człowiek uzbrojony został bowiem w nowoczesną technikę i posiada możliwości oddziaływania na świat zwierząt, w tym decydowania o ich istnieniu, bez konieczności bezpośredniego kontaktu ze zwierzyną. Co więcej, chowającym zwierzę jest ten, kto dla własnej korzyści przez dostarczenie schronienia i utrzymania objął je pieczą, a więc za chowającego powinno zostać uznane również państwo w odniesieniu do dzikiej zwierzyny przebywającej na obszarach, na których obowiązuje zakaz polowania ${ }^{14}$. Nadto, skoro gospodarka łowiecka obejmuje hodowlę zwierzyny, to także mieszczący się w tym pojęciu chów zwierząt łownych ${ }^{15}$. Przedstawione poglądy nie zostały zasadniczo podtrzymane w doktrynie i orzecznictwie. W szczególności podkreślano brak istnienia takiej władzy nad zwierzętami i takiej ich zależności od człowieka, aby można było mówić o chowie zwierząt

11 L. Jastrzębski, Glosa do wyroku SN z dnia 9.03.1973r., I CR 58/73, „Nowe Prawo” 1974, nr 9.

12 A. Agopszowicz, Glosa do wyroku SN z dnia 19.04.1974r., II CR 157/74, „Orzecznictwo Sądów Polskich i Komisji Arbitrażowych” 1975, nr 5.

13 Uchwała SN z dnia 17 października 1991 r., III CZP 100/91, „Orzecznictwo Sądów Polskich” 1992, nr 7.

${ }_{14}$ Z.K. Nowakowski, Glosa do wyroku SN z dnia 17.06.1966r., I CR 360/66, „Orzecznictwo Sądów Polskich i Komisji Arbitrażowych” 1967, nr 7-8.

15 A. Agopszowicz, op.cit. 
i objęciu ich pieczą ${ }^{16}$. Aktualnie za dominujący uważa się pogląd, zgodnie $z$ którym działania podejmowane wobec zwierząt wolno żyjących w ramach gospodarki łowieckiej i ochrony gatunkowej nie są uznawane za chów i nie stanowią o objęciu zwierząt bezpośrednim nadzorem, a zatem regulacja art. 431 Kodeksu cywilnego nie znajdzie zastosowania w odniesieniu do szkód wyrządzanych przez te zwierzęta.

Wobec znaczenia, jakie przedstawiają dla państwa zwierzęta wolno żyjące, a w szczególności zwierzyna łowna i zwierzęta chronione, będące dobrem ogólnonarodowym i elementem środowiska przyrodniczego, a także dalszego ustanawiania wobec nich obowiązków polegających m.in. na dokarmianiu, zapobieganiu chorobom czy zapewnianiu odpowiednich warunków do życia, zagadnienie to może być w dalszym ciągu rozpoznawane pod kątem charakteru i znaczenia ingerencji w życie tych zwierząt, a zatem także odpowiedzialności za szkody przez nie wyrządzane.

Drugą kategorią zwierząt objętych regulacją art. 431 są zwierzęta, którymi ktoś się posługuje. Najczęściej będzie to osoba, która zwierzę chowa, jednakże możliwe są sytuacje, gdy chowający przekaże zwierzę osobie trzeciej dla osiągnięcia celów i w interesie tej osoby ${ }^{17}$, czy to przez dłuższy czas ${ }^{18}$, czy choćby dorywczo lub okazjonalnie $^{19}$.

Odpowiedzialność, której podstawę stanowi przepis art. 431 Kodeksu cywilnego, opiera się na zasadzie winy w nadzorze (culpa in custodiendo), a uwolnienie się od niej wymaga wykazania braku winy własnej lub osób, za które chowający lub posługujący się zwierzęciem ponosi odpowiedzialność. W szczególności okoliczność, że zwierzę uciekło lub zabłąkało się i nie znajdowało się pod nadzorem

${ }^{16}$ S. Rudnicki, Glosa do wyroku SN z dnia 9.03.1973r., I CR 58/73, „Nowe Prawo" 1974, nr 9; A. Szpunar, Glosa do uchwały SN z dnia 17.10.1991r., III CZP 100/91, „Orzecznictwo Sądów Polskich” 1993, nr 3.

17 P. Machnikowski, A. Śmieja, w: System prawa prywatnego. Prawo zobowiązań - część ogólna, red. A. Olejniczak, Warszawa 2009, s. 493; A. Szpunar, Odpowiedzialność za szkody, s. 27.

18 A. Szpunar, Odpowiedzialność za szkody.

19 M. Goettel, Sytuacja zwierzęcia, s. 333. 
w chwili wyrządzenia szkody, nie zwalnia od ponoszenia odpowiedzialności, o ile nie zostanie wykazany brak winy w nadzorze.

\subsection{Zwierzęta objęte zakresem regulacji ustawy Prawo łowieckie}

Ustawa Prawo łowieckie ${ }^{20}$ wprowadza kategorię zwierząt łownych, czyli zwierzyny, i reguluje ochronę tych zwierząt i gospodarowanie ich zasobami w zgodzie $z$ zasadami ekologii oraz racjonalnej gospodarki rolnej, leśnej i rybackiej, enumeratywnie wymieniając ${ }^{21}$ 31 gatunków zwierząt łownych, do których zaliczane są tradycyjnie te gatunki ptaków i ssaków, na które człowiek od dawna polował i nadal poluje w celu pozyskania wartościowego mięsa i cennych skór ${ }^{22}$. Podmiotem obowiązanym do wynagradzania szkód wyrządzonych w uprawach i płodach rolnych przez dziki, łosie, jelenie, daniele i sarny jest dzierżawca lub zarządca obwodu łowieckiego, czyli podmiot, który prowadzi gospodarkę łowiecką wobec wszystkich gatunków zwierząt uznanych za łowne i czerpie korzyści wynikające $z$ otrzymanego uprawnienia do wyrażania zgody na wykonywanie polowania i pozyskiwanie zwierzyny. W przypadku, gdy szkodę w uprawach i płodach rolnych wyrządzi zwierzę łowne podlegające całorocznej ochronie (obecnie jest to jedynie łoś) lub gdy szkoda taka zostanie wyrządzona poza obwodem łowieckim przez zwierzę przynależące do jednego $\mathrm{z}$ pięciu wskazanych gatunków, wówczas odpowiedzialność ponosi Skarb Państwa. Jest on jednocześnie podmiotem uprawnionym do otrzymania ekwiwalentu pieniężnego za bezprawnie pozyskaną zwierzynę łowną każdego gatunku ${ }^{23}$.

${ }^{20}$ Ustawa z dnia 13 października 1995 r. Prawo łowieckie (Dz.U. z 1995 r. $\mathrm{Nr}$ 147, poz. 713).

${ }^{21}$ Rozporządzenie Ministra Środowiska z dnia 11 marca 2005 r. w sprawie ustalenia listy gatunków zwierząt łownych (Dz.U. z 2005 r. Nr 45, poz. 433).

22 W. Radecki, Prawo łowieckie. Komentarz, Warszawa 2012, s. 54.

${ }^{23}$ Rozporządzenie Ministra Środowiska z dnia 21 czerwca 2005 r. w sprawie zwierzyny bezprawnie pozyskanej, Dz.U. z 2005 r. Nr 116, poz. 981. Jako przykład można w tym miejscu wskazać, że ekwiwalent za bezprawnie pozyskanego łosia wynosi 14 tysięcy zł, za dzika - 2300 zł, a za sarnę - 2 tysiące zł. 
Omawiana odpowiedzialność ma charakter obiektywny, niezależny od winy podmiotów zobowiązanych i związana jest $z$ samym faktem prowadzenia gospodarki łowieckiej. Podkreśla się jednak ${ }^{24}$, że celem współczesnej gospodarki łowieckiej jest głównie utrzymywanie równowagi pomiędzy populacjami, tak aby nadmiar zwierzyny nie doprowadził do zniszczenia naturalnej bazy pokarmowej i aby nie był przyczyną nadmiernych szkód w rolnictwie, co przyczynia się do zachowania środowiska przyrodniczego oraz racjonalnego gospodarowania jego zasobami ${ }^{25}$.

\subsection{Zwierzęta objęte zakresem regulacji ustawy o ochronie przyrody}

Ustawa o ochronie przyrody ${ }^{26}$ wprowadza kategorię „Zwierząt objętych ochroną gatunkową", których 792 gatunki zostały enumeratywnie wymienione ${ }^{27}$. Ochrona gatunkowa zwierząt, będąca jedną z form ochrony przyrody i polegająca na zachowaniu, zrównoważonym użytkowaniu i odnawianiu składników przyrody, może przybrać przy tym dwojaki charakter - może być ochroną częściową dopuszczającą możliwość redukcji populacji oraz pozyskiwania osobników danych gatunków lub ochroną ścisłą, co oznacza całoroczną ochronę należących do nich osobników i stadiów ich rozwoju. Państwo ma bowiem obowiązek dbania o przyrodę uważaną za dziedzictwo i bogactwo narodowe, a jednym $z$ przejawów tej ochrony jest możliwość ustanowienia obowiązków określonego zachowania wobec gatunków chronionych, w tym polegających na zakazie ich umyślnego zabijania, okaleczania i chwytania, umyślnego płoszenia, jak również niszczenia siedlisk lub ostoi będących obszarem ich żerowania, a także fotografowania mogącego powodować ich

${ }^{24}$ E. Symonides, Ochrona przyrody, Warszawa 2008, s. 642 i 635.

${ }^{25}$ M. Goettel, Zasady wynagradzania szkód wyrządzonych przez zwierzęta wolno żyjące, „Ochrona Środowiska. Prawo i polityka” 2002, nr 4.

${ }^{26}$ Ustawa z dnia 16 kwietnia 2004 r. o ochronie przyrody, Dz.U. z 2013 r., poz. 627.

${ }^{27}$ Rozporządzenie Ministra Środowiska z dnia 6 października 2014 r. w sprawie ochrony gatunkowej zwierząt, Dz.U. z 2014 r., poz. 1348. 
płoszenie lub niepokojenie. Tym samym co do zasady właściciele nieruchomości muszą znosić obecność i żerowanie zwierząt chronionych. Odstępstwa od ustanowionych zakazów mogą być wprowadzone w przypadku braku rozwiązań alternatywnych i jeżeli nie są szkodliwe dla zachowania we właściwym stanie ochrony dziko występujących zwierząt chronionych, w tym ze względu na potrzebę zapobiegania poważnym szkodom $\mathrm{w}$ mieniu. $\mathrm{W}$ tym miejscu należy podkreślić, że rekompensaty za szkody spowodowane przez te zwierzęta uważane są za istotny element ochrony gatunkowej zwierząt, szczególnie w sytuacji wzrostu liczebności populacji niektórych gatunków ${ }^{28}$.

W trybie omawianej ustawy Skarb Państwa odpowiada za szkody wyrządzone przez żubry - w uprawach, płodach rolnych lub w gospodarstwie leśnym; przez wilki i rysie - w pogłowiu zwierząt gospodarskich; przez niedźwiedzie - w pasiekach, w pogłowiu zwierząt gospodarskich i w uprawach rolnych, oraz przez bobry - wyrządzone $\mathrm{w}$ gospodarstwie rolnym, leśnym lub rybackim ${ }^{29}$. Ustawodawca przewidział wprawdzie możliwość rozszerzenia listy zwierząt chronionych, za które odpowiadać będzie Skarb Państwa, kierując się przy tym potrzebą utrzymania ochrony gatunkowej zwierząt zagrożonych wyginięciem i wyrządzających szkody w gospodarce człowieka, lecz do tej pory nie zostało to dokonane. W przypadku, gdy na terenie parku narodowego, strefy ochronnej zwierząt łownych bądź w rezerwacie przyrody szkodę wyrządzi zwierzę łowne, wówczas ustawa ta odsyła do regulacji Prawa łowieckiego. Szacowanie takich szkód i dokonywanie wypłaty odszkodowań odbywać się zatem będzie według zasad określonych w rozdziale 9 przedmiotowej ustawy, przy czym szkody wyrządzone na terenie parku narodowego lub strefy ochronnej zwierząt łownych pokrywane będą ze środków parku narodowego, a szkody wyrządzone na terenie rezerwatu przyrody ze

${ }^{28}$ Co jest szczególnie widoczne w przypadku szkód wyrządzanych przez kormorany i czaple w stawach rybnych.

${ }^{29}$ Ograniczenie odpowiedzialności Skarbu Państwa do szkód wyrządzonych przez te zwierzęta w określonym mieniu zostało uznane przez Trybunał Konstytucyjny za sprzeczne $z$ konstytucyjną zasadą równości wobec prawa oraz równiej ochrony własności. Zob. wyrok TK z dnia 3 lipca 2013 roku, P 49/11, nr 73/6/A/2013 (Dz.U. poz. 842) i wyrok TK z dnia 21 lipca 2014 r., K 36/14. 
środków regionalnej dyrekcji ochrony środowiska. Należy również zauważyć, że Skarb Państwa odpowiada także za szkody wyrządzone w uprawach i płodach rolnych przez zwierzęta łowne objęte całoroczną ochroną (obecnie zwierzęciem takim jest łoś).

Dokonując podziału zwierząt na poszczególne kategorie, ustawodawca wprowadził regulacje ustanawiające odmienny reżim odpowiedzialności za szkody przez nie wyrządzane. $Z$ uwagi jednak na to, że odpowiedzialność za szkody powodowane przez zwierzęta łowne i chronione, poza ograniczeniami dotyczącymi np. wysokości szkody lub wyłączenia $z$ tego reżimu utraconych korzyści, przewidywana jest jedynie dla wskazanych gatunków $z$ obu tych grup, a więc $z$ pominięciem szkód wyrządzanych przez inne zwierzęta łowne i chronione, pojawić się może pytanie: czy podmioty obowiązane nie powinny odpowiadać na tych zasadach również za szkody wyrządzone przez pozostałe gatunki znajdujące się na liście zwierząt łownych oraz zwierząt chronionych gatunkowo? Niezależnie od przedstawianych poglądów, zgodnie z którymi Skarb Państwa powinien odpowiadać za szkody wyrządzone przez żyjące na wolności zwierzęta chronione oraz zwierzynę łowną jako „chowający”, argumentami w dyskusji winny być zapisy stanowiące, iż zwierzyna łowna w stanie wolnym, jako dobro ogólnonarodowe, stanowi własność Skarbu Państwa, jak również, że zwierzę nie jest rzeczą, a w sprawach nieuregulowanych stosuje się do zwierząt odpowiednio przepisy dotyczące rzeczy.

\section{Status prawny zwierząt}

Pozycja prawna zwierząt została ukształtowana w drodze zapisu, iż „zwierzę nie jest rzeczą”, w sprawach zaś nieuregulowanych w ustawie do zwierząt stosuje się odpowiednio przepisy dotyczące rzeczy. Tego rodzaju podejście określa się jako przewrót w polskiej cywilistyce $^{30}$, ponieważ do tej pory co do zasady zwierzęta wyodrębnione ze środowiska naturalnego i pozostające pod władzą człowieka,

${ }^{30}$ M. Goettel, Sytuacja prawna zwierząt $w$ świetle przepisów Kodeksu cywilnego o porzuceniu i zawłaszczeniu rzeczy, w: Współczesne problemy prawa 
a więc będące przedmiotami materialnymi i posiadające cechę samoistności, traktowane były jak rzeczy. Szczególne rozwiązanie przyjęto w stosunku do ryb i innych zwierząt wodnych, będących przed odłowieniem częścią składową nieruchomości gruntowej, na której znajdują się wody powierzchniowe płynące, i częścią wód morskich lub wód powierzchniowych płynących, które po wyłowieniu stanowią pożytki wody.

Wątpliwości budził jednak status prawny zwierząt dzikich. Większość przedstawicieli doktryny opowiedziała się za stanowiskiem wyrażonym przez Sąd Najwyższy w wyroku z dnia 9 marca 1973 roku $^{31}$, zgodnie $z$ którym zwierzęta wolno żyjące nie mogą zostać zaliczone do kategorii rzeczy, ponieważ nie ma możliwości ich zindywidualizowania, nie są dobrami samoistnymi, a także nie są poddane władztwu człowieka w sposób, który umożliwiałby wykonywanie uprawnień właścicielskich, czyli prawa korzystania i rozporządzania. $Z$ tych zatem przyczyn państwo odpowiada za szkody wyrządzone przez takie zwierzęta tylko wtedy, gdy ustawa tak stanowi ${ }^{32}$. Część przedstawicieli doktryny prezentowała jednak stanowisko ${ }^{33}$, zgodnie $z$ którym nie jest istotne to, czy zwierzęta mogą podlegać „władztwu fizycznemu”, lecz to, czy mogą one podlegać władztwu prawnemu. „O tym zaś przesądził ustawodawca, uznawszy, że zwierzyna w stanie wolnym stanowi własność Państwa ${ }^{34}$. Nadto, stosowanie istniejących środków technicznych pozwalać ma na przyjęcie, że zwierzyna jest zindywidualizowana, w tym także dzięki corocznej inwentaryzacji gatunków sporządzanej w ramach łowieckiego planu hodowlanego ${ }^{35}$. Wskazywano również na możliwość obrotu żywą zwierzyną przez zarządcę lub dzierżawcę obwodu

prywatnego. Księga pamiątkowa ku czci Profesora Edwarda Gniewka, red. J. Gołaczyński, P. Machnikowski, Warszawa 2010, s. 159.

31 Wyrok SN z dnia 9 marca 1973r., I CR 58/73, „Nowe Prawo” 1974, nr 8.

32 S. Rudnicki, op.cit.; J. Ignatowicz, System prawa cywilnego. Prawo własności $i$ inne prawa rzeczowe, Warszawa 1977, s. 352, cyt. za: M. Bednarek, Mienie. Komentarz do art. 44-55 Kodeksu cywilnego, Kraków 1997, s. 84; M. Goettel, Sytuacja zwierzęcia, s. 39.

${ }^{33}$ L. Jastrzębski, Glosa do wyroku Sądu Najwyższego; A. Agopszowicz, op.cit.

34 A. Agopszowicz, op.cit.

35 L. Jastrzębski, Uwagi uzupetniające glosę do wyroku SN z dnia 9.03.1973r, I CR 58/73, „Nowe Prawo” 1975, nr 6. 
łowieckiego oraz na uznanie płynących wód powierzchniowych za własność w rozumieniu cywilistycznym ${ }^{36}$. Prezentowane były również poglądy kwestionujące wąskie rozumienie pojęcia rzecz ${ }^{37}$.

Wejście w życie art. 2 ustawy o ochronie zwierząt zawierającej zapis, że „zwierzę, jako istota żyjąca, zdolna do odczuwania cierpienia, nie jest rzeczą”, poprzedzone było dyskusją, w której kluczowy udział przypisuje się obrońcom praw zwierząt uznających przedmiotową kwestię za zagadnienie bioetyczne, zakończoną tak zwaną dereifikacją zwierzęcia. Zgodnie $\mathrm{z}$ zapisami ustawy $\mathrm{w}$ sprawach w niej nieuregulowanych do zwierząt stosować należy odpowiednio przepisy dotyczące rzeczy, a zatem uwzględniając, że mamy do czynienia $z$ istotą żyjącą, zdolną do odczuwania cierpienia fizycznego i psychicznego, któremu człowiek winien jest zapewnić ochronę i opiekę $e^{38}$. Ustalenie, czy dany przepis ma być stosowany wprost, czy z pewnymi modyfikacjami, wymagać będzie odwołania się do wykładni systemowej i funkcjonalnej.

W dalszym ciągu za aktualne należy uznać zagadnienie, czy zwierzęta wolno żyjące stanowią materialne dobra samoistne, czy niesamoistne, a także czy (niezależnie od jego rozstrzygnięcia) w stosunkach prawnorzeczowych uznawane będą za rzecz. Należy bowiem rozważyć, jakie przesłanki decydują o uznaniu samoistności zwierzęcia i jak znaczący powinien być zakres i charakter władzy nad zwierzęciem, aby zostało uznane za samoistne oraz $z$ jakim momentem miałoby to nastąpić. Czy zwierzę żyjące na wolności, zaopatrzone w nadajnik geolokalizacyjny, oraz zwierzę osiadłe, które urodzone w danym łowisku stale w nim bytuje, nie jest wystarczająco zindywidualizowane? Czy wobec możliwości prowadzenia nagonki i odstrzału zwierzyny łownej nie jest ona poddana władztwu

${ }^{36}$ Idem, Glosa do wyroku SN. Do krytycznych uwag zawartych w tejże glosie przyłączyli się także: A. Szpunar, W. Wanatowska, Przegląd Orzecznictwa SN za II pótrocze 1974, „Nowe Prawo” 1975, nr 7-8.

37 Cyt. za: R. Mikosz, w: System prawa prywatnego. Prawo rzeczowe, red. E. Gniewek, Warszawa 2013.

${ }^{38}$ E. Łętowska, Dwa cywilnoprawne aspekty praw zwierzat, w: Studia z prawa prywatnego. Księgapamiątkowa ku czci Profesor Biruty Lewaszkiewicz-Petrykowskiej, red. A. Szpunar, Łódź 1997, s. 83; Wyrok NSA w Warszawie z dnia 3 listopada 2011 r., II OSK 1628/11, Lex nr 115162. 
człowieka? Jednakże czy pies domowy, który od kilku dni przebywa na polach i w lasach, jest nadal dobrem samoistnym, poddanym takiemu władztwu? Nadto czy ewentualny brak samoistności determinuje niemożność bycia przez takie zwierzę cywilnoprawnym przedmiotem własności?

W doktrynie ${ }^{39}$ zaprezentowany został postulat, aby do art. 45 Kodeksu cywilnego dodać § 2 stanowiący, iż: „w stosunkach cywilnoprawnych za rzeczy uważa się także zwierzęta. Do zwierząt stosuje się przepisy o rzeczach, chyba że przepis szczególny stanowi inaczej”. Tym samym miałoby dojść do powstania fikcji prawnej polegającej na tym, że zwierzę uważane byłoby za rzecz, pomimo że nie jest rzeczą w znaczeniu ontologicznym (na skutek dereifikacji) i w znaczeniu techniczno-prawnym (ze względu na brak samoistności). Status prawny zwierzęcia, a zatem możliwość uznania go za rzecz w znaczeniu cywilnoprawnym, jest zaś zagadnieniem istotnym dla określenia charakteru prawa przypisanego do zwierzęcia, a w dalszej kolejności dla odpowiedzialności za szkody wyrządzane przez zwierzęta wolno żyjące.

\section{Prawo własności przysługujące wobec zwierząt}

Przed wejściem w życie ustawy o ochronie zwierząt uznawano, że jeśli zwierzę było przedmiotem materialnym i posiadało cechę samoistności, wówczas stanowiło przedmiot własności w rozumieniu art. 140 Kodeksu cywilnego. Dzikie zwierzęta nie były uważane przez większość przedstawicieli doktryny za rzeczy, a w dalszej kolejności za przedmiot własności w sensie cywilistycznym, mimo że ustawa łowiecka zawierała zapis, zgodnie $\mathrm{z}$ którym zwierzyna stanowiła własność państwa ${ }^{40}$. Tę rozbieżność argumentowano w różnoraki sposób.

${ }^{39}$ M. Nazar, Normatywna dereifikacja zwierzat, w: Prawna ochrona zwierząt, red. M. Mozgawa, Lublin 2002, s. 148.

${ }^{40}$ Ustawa $z$ dnia 17 czerwca 1959 r. o hodowli, ochronie zwierząt łownych i prawie łowieckim, Dz.U. z 1973 r. Nr 33, poz. 197. 
W pierwszej kolejności wskazać należy na pogląd zaprezentowany przez Fryderyka Zolla ${ }^{41}$, zgodnie $z$ którym prawo własności zwierzyny łownej będzie jedynie prawem podobnym do praw rzeczowych, ponieważ zwierząt tych nie można opanować jak rzeczy, a władztwo nad zwierzyną jest mniej intensywne niż władztwo nad rzeczą. Następnie przedstawiana była koncepcja dokonująca rozróżnienia na własność zwierząt w stanie wolnym w szerokim rozumieniu konstytucyjnym i wąskim znaczeniu cywilnym. Zgodnie z nią, przysługującą państwu własność zwierzyny łownej należy rozumieć szeroko, jako mienie, które obejmuje zarówno własność, jak i inne prawa majątkowe. Ówcześnie obowiązująca Konstytucja $^{42}$ posługiwała się bowiem jedynie pojęciami „własność” i „prawo dziedziczenia”. Mienie stanowiło zaś jurydyczny odpowiednik prawa

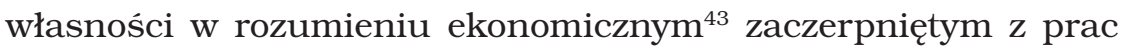
Karola Marksa. Omawiana koncepcja była jednak krytykowana ${ }^{44}$. Podnoszono równie $\dot{z}^{45}$, że zapis „Zwierzyna w stanie wolnym stanowi własność państwa” musi być wypełniony jakąś treścią i jedynym możliwym rozwiązaniem jest odwołanie się do przepisu art. 140 Kodeksu cywilnego".

Charakter prawa własności przysługującego Skarbowi Państwa wobec zwierzyny łownej stanowi przedmiot rozważań doktryny również w ostatnich dziesięcioleciach, na gruncie regulacji znajdujących się w obowiązującej Konstytucji ${ }^{46}$, która wyraźne rozróżnia własność oraz inne prawa majątkowe. Zdecydowana większość doktryny przedstawia stanowisko, iż operowanie pojęciem własności w znaczeniu konstytucyjnym w obowiązującym stanie prawnym jest

${ }^{41}$ F. Zoll, Prawo cywilne $w$ zarysie, t. 2: Prawo rzeczowe, Kraków 1947, s. 6-7.

${ }^{42}$ Konstytucja Polskiej Rzeczypospolitej Ludowej z dnia 22 lipca 1952 r., Dz.U. z 1952 r. Nr 33, poz. 23.

${ }^{43}$ T. Dybowski, Ochrona własności $w$ polskim prawie cywilnym. „Rei vindicatio - actio negatoria”, Warszawa 1969, s. 14-19, 22.

${ }^{44}$ L. Jastrzębski, Glosa do wyroku SN; idem, Uwagi uzupetniające glosę do wyroku SN. Do krytycznych uwag zawartych w tejże glosie przyłączyli się także:

A. Szpunar, W. Wanatowska, op.cit., s. 1051.

45 A. Agopszowicz, op.cit.

${ }^{46}$ Konstytucja Rzeczypospolitej Polskiej z dnia 2 kwietnia 1997 r., Dz.U. z 1997 r. Nr 78, poz. 483. 
bardzo wątpliwe ${ }^{47}$. Mając jednak na uwadze treść art. 1 ust. 1 i 2 ustawy o ochronie zwierząt, w doktrynie i orzecznictwie przeważa pogląd ${ }^{48}$, zgodnie $z$ którym „prawo własności” przysługujące wobec zwierzęcia, wprawdzie podmiotowe, majątkowe i bezwzględne, lecz posiadające atrybuty jedynie analogiczne do prawa własności, nie będzie prawem własności w rozumieniu Kodeksu cywilnego. Wskazuje się przy tym na ograniczenia atrybutu korzystania, polegające np. na zakazie znęcania się nad zwierzętami oraz nakazie zapewnienia im ochrony, jak również na ograniczenia w zakresie rozporządzania przejawiające się m.in. w zakazie wprowadzania do obrotu zwierząt domowych na targowiskach czy też w zakazie porzucenia zwierzęcia. W przypadku zaś zwierząt łownych w stanie wolnym, będących zgodnie $z$ aktualnie obowiązującymi regulacjami dobrem ogólnonarodowym i własnością Skarbu Państwa, za takie ograniczenia uznawana jest w szczególności możliwość rozporządzania zwierzyną co do zasady wyłącznie w drodze wydzierżawiania lub ustanawiania zarządu nad obwodami łowieckimi. Należy jednak w tym miejscu zauważyć, że na właściciela każdej rzeczy nałożone są pewne ograniczenia w korzystaniu i rozporządzaniu nią. Może on bowiem czynić ze swoją rzeczą wszystko, co nie jest zabronione przez ustawy, zasady współżycia społecznego i co nie pozostaje w sprzeczności ze społeczno-gospodarczym przeznaczeniem tego prawa. Istota prawa własności rozumianego jako najszersze prawo

47 R. Stec, Uprawianie łowiectwa i prowadzenie gospodarki łowieckiej. Uwarunkowania administracyjnoprawne, cywilnoprawne i organizacyjne, Warszawa 2012, s. 72; W. Radecki, Prawo łowieckie, s. 61. Do poglądu tego przychylają się także: A. Stelmachowski, K. Zaradkiewicz, w: System prawa prywatnego. Prawo rzeczowe; J. Sommer, Prawo wtasności a ochrona środowiska w warunkach gospodarki rynkowej, w: Ochrona środowiska a prawo własności, Wrocław 2000, s. 16. Autorzy ci powołują się na wyrok TK z dnia 12 stycznia 1999 r., P 2/98, Dz.U. z 1999 Nr 3, poz. 30 oraz wyrok TK z dnia 12 stycznia 2000 r., P 11/98, „Orzecznictwo Trybunału Konstytucyjnego” 2000, nr 1.

${ }^{48}$ R. Mikosz, w: System prawa prywatnego. Prawo rzeczowe, s. 494-498; M. Goettel, Sytuacja zwierzęcia, s. 60 i 61; M. Nazar, op.cit., s. 136; E. Skowrońska-Bocian, M. Warciński, w: Kodeks cywilny. Komentarz art. 1 - 449.10, red. K. Pietrzykowski, Warszawa 2013, s. 197; wyrok NSA z dnia 3 listopada 2011 r., II OSK 1628/11. Pogląd przeciwny wyraża: Ł. Żelechowski, w: Kodeks cywilny. Komentarz, red. K. Osajda, Warszawa 2013, s. 45. 
do rzeczy określana jest zaś przez ustalenie owych ograniczeń ${ }^{49}$. Prawo własności Skarbu Państwa wobec zwierzyny łownej w stanie wolnym nie zostało ustanowione przez wskazanie poszczególnych uprawnień właścicielskich, lecz w drodze ustanowienia prawa własności i wprowadzenia ograniczeń w jego wykonywaniu. Otwarte wydaje się zagadnienie, czy przedmiotowe ograniczenia naruszają istotę prawa własności w rozumieniu cywilnoprawnym, w szczególności mając na uwadze charakter przesłanek leżących u podstaw wprowadzenia tych ograniczeń oraz nakaz odpowiedniego stosowania do zwierząt przepisów dotyczących rzeczy. Wojciech Radecki uważa $^{50}$, że w związku $z$ tym, iż nakaz odpowiedniego stosowania do zwierząt przepisów dotyczących rzeczy odnosi się do przepisów cywilnoprawnych, „wolno utrzymywać, że prawo własności w ujęciu art. 2 Prawa łowieckiego jest prawem cywilnym, aczkolwiek mocno naznaczonym elementami publicznoprawnymi”. Autor powołuje się przy tym na pogląd wyrażony przez Zbigniewa Radwańskiego ${ }^{51}$, iż „zapis zawarty w ust. 2 art. 1 ustawy o ochronie zwierząt $z$ pewnością odnosi się do przepisów cywilnoprawnych, regulujących prawo własności i obrót zwierzętami. Natomiast ograniczeniu ulega wykonywanie uprawnień właścicielskich wobec zwierząt - w szczególności przez ustanowienie zakazu okrutnego ich traktowania lub rażącego zaniedbywania”. Podobnie Roman $\mathrm{Stec}^{52}$ uważa, że chodzi tu o własność w znaczeniu cywilistycznym, zawierającym wyraźne elementy publicznoprawne.

Na uwagę zasługuje także w tym miejscu argumentacja, którą posługują się przedstawiciele Ministerstwa Środowiska, wyjaśniając przyczyny braku odpowiedzialności Skarbu Państwa, na zasadach innych niż ogólne, za szkody wyrządzane przez te gatunki zwierzyny łownej, za które nie odpowiada on na zasadach wskazanych w ustawie Prawo łowieckie. Przyjęto bowiem szerokie rozumienie „własności” zwierzyny łownej w stanie wolnym, przy czym ustano-

49 B. Rakoczy, Własność wód $w$ prawie polskim, „Przegląd Prawa Ochrony Środowiska” 2013, nr 1, s. 15.

50 W. Radecki, Prawo łowieckie, s. 61.

${ }^{51}$ Z. Radwański, Prawo cywilne - część ogólna, Warszawa 2004, s. 114.

${ }^{52}$ R. Stec, op.cit., s. 72 i 74. 
wienie tego prawa wynikać ma z potrzeby wyeliminowania „wątpliwości, czyją własnością są zwierzęta łowne (właściciela gruntu, na którym przebywają, czy państwa) oraz kto może nimi dysponować. Problemy te mogłyby $z$ kolei skutkować brakiem ochrony zwierzyny przed nadmiernym pozyskaniem"53. Należy jednak zauważyć, że takim zabezpieczeniem przed pozyskaniem zwierzyny jest istniejąca regulacja art. 15 ust. 2 ustawy Prawo łowieckie, zgodnie z którym „Zwierzyna bezprawnie pozyskana stanowi własność Skarbu Państwa” i przepisy ustanawiające wysokość ekwiwalentu płaconego za zwierzynę bezprawnie pozyskaną. Przyznania tak rozumianej „własności” nie sposób nadto uznać za konsekwencję statusu zwierzyny łownej będącej dobrem ogólnonarodowym, ponieważ takim dobrem są również zwierzęta chronione gatunkowo, a wobec nich nie ustanowiono „prawa własności” Skarbu Państwa. Nadto czyżby ustawodawca nie obawiał się bezprawnego pozyskiwania zwierząt chronionych gatunkowo, a więc szczególnie cennych, skoro nie ustanowił wobec nich analogicznego „prawa własności”?

W świetle zaprezentowanych rozważań zasadne wydaje się poddanie analizie zagadnienia, $z$ jakich przyczyn pojęciu „własność” znajdującemu się w art. 2 ustawy Prawo łowieckie w dalszym ciągu przypisuje się znaczenie inne, niż wynika to $z$ obowiązujących przepisów prawa. Jakie bowiem przekonywające racje miałyby stanowić o tym, że ustawodawca, posługując się pojęciem „własność”, miał w rzeczywistości na myśli „mienie” lub „inne prawa majątkowe", które to pojęcia posiadają inne znaczenie? Punktem wyjścia dla każdej wykładni prawa powinna być przecież wykładnia językowa, a odstąpienie od niej powinno następować jedynie absolutnie wyjątkowo. Nadto zgodnie $z$ dyrektywą języka prawnego, jeśli prawodawca nadał określonym wyrażeniom swoiste znaczenie prawne, to należy je rozumieć właśnie w ten sposób. Mając zaś na uwadze zakaz wykładni homonimicznej, tym samym zwrotom nie powinno się nadawać różnych znaczeń, przy czym gdy prawodawca chce nadać tym samym wyrażeniom inne znaczenie, wówczas po-

53 Departament Prawny Ministerstwa Środowiska, Opinia Departamentu Prawnego Ministerstwa Środowiska $w$ sprawie postępowania ze zwierzętami łownymi $w$ szczególnych przypadkach z dnia 26 marca 2013 r. 
winien to wyraźnie zaznaczyć w tekście prawnym. Podkreślenia również wymaga, że obywatele mają prawo działać w zaufaniu do tego, co zostało napisane w tekstach prawnych, a nie do tego, co prawodawca zamierzał, czy też chciał osiągnąc $c^{54}$.

$Z$ uwagi na wielość poglądów dotyczących przedmiotowych zagadnień, których - jak się wydaje - nie rozstrzygają dostatecznie regulacje zawarte $\mathrm{w}$ ustawie o ochronie zwierząt, zagadnienie statusu prawnego i właścicielskiego zwierząt, szczególnie w kontekście odpowiedzialności za szkody wyrządzane przez zwierzęta wolno żyjące, ma w dalszym ciągu charakter otwarty.

\section{STRESZCZENIE}

Systematyka i zagadnienie własności zwierząt oraz ich statusu prawnego w kontekście problematyki odpowiedzialności za szkody przez nie wyrządzane

Odpowiedzialność za szkody wyrządzone przez trzy kategorie zwierząt została przez ustawodawcę uregulowana w sposób odbiegający od zasad ogólnych. Odpowiedzialnością przewidzianą w art. 431 Kodeksu cywilnego objęte zostały szkody wyrządzane m.in. przez wszystkie zwierzęta chowane, jednakże istnieje wielość poglądów dotyczących zakresu znaczeniowego tego pojęcia. Odpowiedzialność odszkodowawcza wynikająca $z$ ustawy Prawo łowieckie oraz z ustawy o ochronie przyrody dotyczy szkód wyrządzanych przez zwierzęta niektórych tylko gatunków objętych regulacjami tych ustaw. Zgodnie $z$ aktualnym prawodawstwem do zwierząt należy stosować odpowiednio przepisy dotyczące rzeczy, a zwierzyna łowna została uznana za własność Skarbu Państwa. Status prawny i własnościowy zwierząt ukształtowany jest w sposób niejednolity, co prowadzi do powstawania rozbieżnych interpretacji tych zagadnień, także w kontekście szkód przez nie wyrządzanych.

Słowa kluczowe: zwierzęta; odpowiedzialność odszkodowawcza; status prawny; prawo własności; podziały

\footnotetext{
${ }^{54}$ L. Morawski, Zasady wykładni prawa, Toruń 2010, s. 74, 87-88, 107, 120-121; rozporządzenie Prezesa Rady Ministrów z dnia 20 czerwca 2002 r. w sprawie „Zasad techniki prawodawczej”, Dz.U. z 2002 r. Nr 100, poz. 908.
} 


\section{SUMMARY}

Classification and the issue of ownership of animals as well as their legal status according to liability for damage caused by them

Liability for damage caused by three categories of animals was regulated by the legislator in the way diverging from the general principles. Liability provided for in s. 431 of the Civil Code covers damage caused by, including but not limited, all animals which are raised. However, there are different views concerning the scope of the meaning of this term. Liability for damages regulated in the Game Act and the Wildlife Protection Act refers to damage caused by only some species of animals covered by the provisions of those Acts. Under the current legislation, the provisions relating to things should apply to animals accordingly, and game has been regarded as the property of the State Treasury. The legal and ownership status of animals has been determined in an inconsistent way, which leads to conflicting interpretations of the above issues, including the aspect of the damage caused by such animals.

Keywords: animals; liability for damages; legal status; the ownership right; classifications

\section{BIBLIOGRAFIA}

Agopszowicz A., Glosa do wyroku SN z dnia 19.04.1974r., II CR 157/74, „Orzecznictwo Sądów Polskich i Komisji Arbitrażowych” 1975, nr 5.

Bednarek M., Mienie. Komentarz do art. 44-55 Kodeksu cywilnego, Kraków 1997.

Dybowski T., Ochrona własności $w$ polskim prawie cywilnym. „Rei vindicatio - actio negatoria", Warszawa 1969.

Goettel M., Sytuacja prawna zwierząt $w$ świetle przepisów Kodeksu cywilnego o porzuceniu i zawtaszczeniu rzeczy, w: Współczesne problemy prawa prywatnego. Księga pamiątkowa ku czci Profesora Edwarda Gniewka, red. J. Gołaczyński, P. Machnikowski, Warszawa 2010.

Goettel M., Sytuacja prawna zwierzęcia $w$ prawie cywilnym, Warszawa 2013.

Goettel M., Zasady wynagradzania szkód wyrządzonych przez zwierzęta wolno żyjace, „Ochrona Środowiska. Prawo i polityka” 2002, nr 4. 
Ignatowicz J., System prawa cywilnego. Prawo własności i inne prawa rzeczowe, Warszawa 1977.

Jastrzębski J., Glosa do wyroku SN z dnia 9.03.1973r., I CR 58/73, „Nowe Prawo” 1974, nr 9.

Jastrzębski J., Uwagi uzupetniające glosę do wyroku SN z dnia 9.03.1973 r., I CR 58/73, „Nowe Prawo” 1975, nr 6.

Łętowska E., Dwa cywilnoprawne aspekty praw zwierzą, w: Studia z prawa prywatnego. Księga pamiątkowa ku czci Profesor Biruty Lewaszkiewicz-Petrykowskiej, red. A. Szpunar, Łódź 1997.

Machnikowski P., Śmieja A., w: System prawa prywatnego. Prawo zobowiązań - część ogólna, red. A. Olejniczak, Warszawa 2009.

Mikosz R., w: System prawa prywatnego. Prawo rzeczowe, red. E. Gniewek, Warszawa 2013.

Morawski L., Zasady wykładni prawa, Torun 2010.

Nazar M., Normatywna dereifikacja zwierząt, w: Prawna ochrona zwierząt, red. M. Mozgawa, Lublin 2002.

Nowakowski Z.K., Glosa do wyroku SN z dnia 17.06.1966r., I CR 360/66, „Orzecznictwo Sądów Polskich i Komisji Arbitrażowych” 1967, nr 7-8.

Radecki W., Prawo łowieckie. Komentarz, Warszawa 2012.

Radecki W., Ustawa o ochronie zwierzat. Komentarz, Warszawa 2012.

Radwański Z., Prawo cywilne - część ogólna, Warszawa 2004.

Rakoczy B., Własność wód $w$ prawie polskim, „Przegląd Prawa Ochrony Środowiska” 2013, nr 1.

Rudnicki S., Glosa do wyroku SN z dnia 9.03.1973r., I CR 58/73, „Nowe Prawo" 1974, nr 9.

Skowrońska-Bocian E., Warciński M., w: Kodeks cywilny. Komentarz art. 1 - 449.10, red. K. Pietrzykowski, Warszawa 2013.

Sommer J., Prawo własności a ochrona środowiska w warunkach gospodarki rynkowej, w: Ochrona środowiska a prawo własności, Wrocław 2000.

Stec R., Uprawianie łowiectwa i prowadzenie gospodarki łowieckiej. Uwarunkowania administracyjnoprawne, cywilnoprawne i organizacyjne, Warszawa 2012.

Stelmachowski A., Zaradkiewicz K., w: System prawa prywatnego. Prawo rzeczowe, red. E. Gniewek, Warszawa 2013.

Strzałko J., Słownik terminów biologicznych, Poznań 2006.

Symonides E., Ochrona przyrody, Warszawa 2008.

Szpunar A., Glosa do uchwały SN z dnia 17.10.1991r., III CZP 100/91, „Orzecznictwo Sądów Polskich” 1993, nr 3.

Szpunar A., Odpowiedzialność za szkody wyrządzone przez zwierzęta i rzeczy, Warszawa 1985. 
Szpunar A., Wanatowska W., Przegląd Orzecznictwa SN za II półrocze 1974, „Nowe Prawo” 1975, nr 7-8.

Zoll F., Prawo cywilne $w$ zarysie, t. 2: Prawo rzeczowe, Kraków 1947.

Żelechowski Ł., w: Kodeks cywilny. Komentarz, red. K. Osajda, Warszawa 2013. 